(The 3rd ICBS-2013)

\title{
IDENTIFICATION OF POLYMORPHISM ON SIMPLE SEQUENCE REPEATS MARKERS ASSOCIATED WITH BROWN PLANTHOPPER RESISTANCE GENES IN TWENTY RICE GENOTYPES AND THEIR GENETIC RELATIONSHIP
}

\author{
Nono Carsono ${ }^{*}$, Yessikha V. Barus ${ }^{4}$, Santika Sari5 ${ }^{5}$, Winny D. Widarmi ${ }^{5}$, Danar Dono², \\ Yayan Sumekar ${ }^{3}$, and Murdaningsih H.K ${ }^{1}$ \\ ${ }^{1}$ Staff, Lab of Plant Biotechnology and Breeding, Faculty of Agriculture, Universitas Padjadjaran, Jatinangor, \\ Bandung - Sumedang 45363. E-mail: ncarsono@unpad.ac.id (Author for correspondence). \\ ${ }^{2}$ Staff, Lab of Entomology, Faculty of Agriculture, Universitas Padjadjaran, Jatinangor, \\ Bandung - Sumedang 45363. \\ ${ }^{3}$ Staff, Lab of Weed Science, Faculty of Agriculture, Universitas Padjadjaran, Jatinangor, \\ Bandung - Sumedang 45363. \\ ${ }^{4}$ Student, Agrotechnology Study Program, Faculty of Agriculture, Universitas Padjadjaran, Jatinangor, \\ Bandung - Sumedang 45363. \\ ${ }^{5}$ Student, Master Program in Plant Breeding, Faculty of Agriculture, Universitas Padjadjaran, Jatinangor, \\ Bandung - Sumedang 45363.
}

\begin{abstract}
Brown planthopper is one of the most destructive insect pest of rice in Indonesia and other Asian countries. Pyramiding some brown planthopper resistance genes is a valuable approach to create more durable resistance against the pest. The objective of this study was to identify polymorphisms of Brown Planthopper Resistance genes (Bph) on 20 genotypes of rice, and to obtain genetic relationship among genotypes tested. The experiment was conducted from June to September 2012 at Green House and Laboratory of Plant Analysis and Biotechnology, Faculty of Agriculture, Universitas Padjadjaran, Jatinangor. Twenty genotypes were analyzed, and two of them were used as check varieties. Simple Sequence Repeat (SSR) markers were applied to detect Bph3, Bph4, Qbph3, and Qbph4 genes. Polymorphic levels were analyzed by calculating PIC (Polymorphic Information Content). The grouping of rice genotypes were done based on principal components analysis (PCA) of SSR data, and the genetic relationship based on the presence of Bph genes was estimated using UPGMA (Unweighted Pair Group With Arithmetic mean). Results showed that RM313, RM8072, RM8213, RM5953, RM586, and RM589 markers were polymorphic. Rice genotypes PTB 33, Diah Suci, Cibogo, Cisantana, Digul, Ciherang, Inpari 13, Inpari 10, and Memberamo had Bph3, Qbph3, Bph4, and Qbph4. Meanwhile Bph3, Qbph3, and Bph4 were supposed to be belonged by IR 64, Aek Sibundong, Batang Gadis, IR 66, and Mekongga. Kalimas and Tukat Penatu had Bph3, Qbph3, dan Qbph4. IR 74 had Bph3 and Qbph3, and Fatmawati had Bph3 and Bph4. UPGMA clustering resulted in two main clusters, in which the first cluster consisted of 2 subclusters. PTB-33 was closely related with Memberamo, Tukat Penatu, Digul, Diah Suci, and Kalimas. The SSR markers used in this study were proven to be valuable in molecular detection of $B p h$ genes and in estimating genetic relationsips of rice genotypes. PTB-33 was a good donor of resistance genes, as well as Memberamo, Tukat Penatu, Digul, Diah Suci, and Kalimas which were identified as promising donors in rice breeding resistance to brown planthopper.
\end{abstract}

Key words : Bph gene, Brown Planthopper, Genetic relationship, SSR markers.

\section{INTRODUCTION}

Indonesia and the other Asian countries are currently facing problems in securing supplies of rice. One reason of the decline in rice production is the brown planthoppers (BPH; Nilaparvata lugens Stal.) pests. BPH is a global threat because not only attacking rice crops in Indonesia, but also attacking rice crops in China, Thailand, Vietnam, India, Bangladesh, Malaysia, Philippines, Japan, and Korea (Baehaki, 2007). Interesting phenomenon in the interaction between the rice varieties to brown planthopper is the appearance of biotype, the

ISSN 2413-0877 @ 2015 The Authors.

Published by KnowledgeE Publishing Services This is an open access article under the CC BY-NC-ND license (http://creativecommons.org/licenses/by-nc-nd/4.0)

Selection and Peer-review under responsibility of the 3rd ICBS-2013

Doi http://dx.doi.org/10.18502/kls.v2i1.124 
strains of brown planthoppers that have adapted physiologically or genetically to certain varieties. In Indonesia, a lot of BPH biotypes were found, such as biotype 2, 3, 4 and also a possible mix among them. To prevent the spread of brown planthoppers, control action has been carried out in many ways since 1970 . One of the most effective, economical, and environmental friendly approach is by using resistant rice varieties. This approach was chosen due to the fact that resistance to brown planthoppers is genetically controlled, which generally based on the resilience of the major genes (Kisimoto, 1981; Mochida, 1978). To identify brown planthopper resistance genes in rice varieties, molecular markers (DNA-based markers) is a promising way to perform such effort. Simple Sequence Repeats is frequently applied for assessing genetic diversity, QTL analysis and other molecular tasks. SSR markers are PCR-based DNA markers in a form of DNA sequence with a long repetition of a nucleotide bases (Foulet et al, 2005). For SSR markers have been known to be associated with the BPH resistance genes: RM589, RM586, RM19291 and RM8072 with Bph3 (Jairin et al., 2007a), RM313 and RM7 with Qbph3 (Sun et al., 2005), RM589 and RM586 with Bph4 (Jairin et al., 2007a), RM5953 and RM8213 with Qbph4 (Sun et al., 2005).

Identification of Bph resistance genes in rice resistant varieties by using SSR markers is valuable tool in order to detect the composition of BPH resistance genes and also to make an attempt on pyramiding some resistance genes into one genotype. Gene pyramiding combines more than two resistance genes into a single genotype achieved through crossbreeding (Sharma et al., 2003), in order to obtain rice varieties with horizontal resistant composted by multiple BPH biotypes which is expected to be more durable. Meanwhile, genetic relationship of rice genotypes based on the presence of their Bph genes should be evaluated for selecting promising parent for hybridization. In this research, testing for polymorphism of SSR markers was evaluated. Level of polymorphism was estimated by counting the PIC (Polymorphic Information Content) value, which was done to determine the informative level of SSR markers used, in which polymorphism occurs due to differences in the number of repetitions of DNA sequences (Liu, 1998). This study was aimed to identify Bph resistance genes on twenty rice genotypes, to assess genetic relationship among genotypes, and to identify better markers for detecting Bph genes especially for Indonesian rice varieties.

\section{MATERIALS AND METHODS}

\section{Plant Materials}

Twenty rice genotypes derived from Indonesian Rice Research Institute (BB Padi Sukamandi) were used: PTB33, Diah Suci, IR74, IR64, Aek Sibundong, Batang Gadis, Cibogo, Cisantana, Digul, Ciherang, Fatmawati, Inpari13, Inpari10, IR66, Kalimas, Mekongga, Memberamo, and Tukat Penatu. IR42 and Taichung 65 were used as check varieties (susceptible). The seeds were germinated on petridish and then sown in trays. Each genotype consisted of 10 plants in pots that were planted in separate pot. Young green leaf from 45-days old plant was taken for DNA analysis.

\section{DNA preparation and SSR analysis}

Molecular markers as listed in Table 1 were applied. These SSR markers were se- 
lected based on literature studies and further confirmed by initial laboratory experiment.

Genomic DNA was isolated from young leaves using CTAB method (Doyle and Doyle, 1987). Concentration of DNA was estimated using spectrophotometer (Rayleigh UV-9200) at wavelength of $260 \mathrm{~nm}$ and $280 \mathrm{~nm}$. Total volume of PCR mixture was $25 \mu \mathrm{L}$, consisted of 9,5 $\mu \mathrm{L}$ Nuclease-free water, 12,5 $\mu \mathrm{L}$ Go Taq $q^{\circledR}$ Green Master Mix, $1 \mu \mathrm{L}$ Forward Primer, $1 \mu \mathrm{L}$ Reverse Primer, and $1 \mu \mathrm{L}$ Template (DNA) 20ng.

Amplification reaction was performed on a thermal cycler (Eppendorf), and programmed as follows: one cycle of $94^{\circ} \mathrm{C}$ for $5 \mathrm{~min}$ for initial denaturation, 36 cycles of $94^{\circ} \mathrm{C}$ for $1 \mathrm{~min}$ for denaturation, $55^{\circ} \mathrm{C}$ for $1 \mathrm{~min}$ for annealing, and $72^{\circ} \mathrm{C}$ for $1 \mathrm{~min}$ for elongation, followed by $72^{\circ} \mathrm{C}$ for $7 \mathrm{~min}$ for final elongation. PCR product was run on agarose gel (3\%) electrophoresis for 45 minutes at 100 volt. Agarose gel was stained with ethidium bromide solution for 20-30 minutes then subsequently visualized in chemidoc gel system.

Table 1. SSR markers used

\begin{tabular}{|c|c|c|c|c|c|c|}
\hline \multirow{2}{*}{ No } & \multirow{2}{*}{$\begin{array}{c}\text { SSR } \\
\text { Markers }\end{array}$} & \multicolumn{2}{|c|}{ Sequence } & \multirow{2}{*}{$\begin{array}{l}\mathrm{PCR} \\
\text { product } \\
\text { size }^{*}\end{array}$} & \multirow{2}{*}{$\begin{array}{l}\text { Bph } \\
\text { target }\end{array}$} & \multirow{2}{*}{ Literature } \\
\hline & & Forward & Reverse & & & \\
\hline 1 & RM7 & ttcgccatgaagtctctcg & cctcccatcatttcgttgtt & $180 \mathrm{bp}$ & Qbph3 & $\begin{array}{l}\text { Sun et al., } \\
2005\end{array}$ \\
\hline 2 & RM586 & $\begin{array}{l}\text { acctcgcgttattaggtacccat } \\
\text { cat }\end{array}$ & $\begin{array}{l}\text { gagatacgccaacgagataccc } \\
\text { aggtt }\end{array}$ & $271 b p$ & $\begin{array}{l}\text { Bph3 } \\
\text { and } \\
\text { Bph4 }\end{array}$ & $\begin{array}{l}\text { Jairin et al. } \\
\quad 2007\end{array}$ \\
\hline 3 & RM589 & ggtcggtggcttaac & ccaaccagacactg & $186 \mathrm{bp}$ & $\begin{array}{l}\text { Bph3 } \\
\text { and } \\
\text { Bph4 }\end{array}$ & $\begin{array}{l}\text { Jairin et al. } \\
\quad 2007\end{array}$ \\
\hline 4 & RM5953 & aaactttctgtgatggtatc & atccttgtctagaattgaca & $129 b p$ & Qbph4 & $\begin{array}{l}\text { Sun et al., } \\
2005\end{array}$ \\
\hline 5 & RM8072 & gatcactcaggtcatccattc & $\begin{array}{l}\text { aatcagagaggctaaagacaat } \\
\text { aat }\end{array}$ & $146 \mathrm{bp}$ & Bph3 & $\begin{array}{l}\text { Jairin et al., } \\
\quad 2007\end{array}$ \\
\hline 6 & RM8213 & agcccagtgatacaaagatg & gcgaggagataccaagaaag & $177 \mathrm{bp}$ & Qbph4 & $\begin{array}{l}\text { Sun et al., } \\
2005\end{array}$ \\
\hline 7 & RM19291 & cacttgcacgtgtcctctgtacg & gtgtttcagttcaccttgcatcg & $146 b p$ & Bph3 & $\begin{array}{l}\text { Jairin et al., } \\
\quad 2007\end{array}$ \\
\hline 8 & RM313 & tgctacaagtgttcttcaggac & gctcaccttttgtgttccac & $111 \mathrm{bp}$ & Qbph3 & $\begin{array}{l}\text { Sun et al., } \\
2005\end{array}$ \\
\hline
\end{tabular}

Note: * Derived from Gramene (2008).

\section{Data analysis}

The PIC value e" 0.5, which was calculated according to Botstein et al. (1980): Molecular data in terms of PCR bands derived from image visualization system using Geldoc under UV transilluminator (captured by Genesnap software program) was interpreted. The images were then analyzed using a GeneTool software (Syngene, UK) for ensuring the differences in size of each band. Polymorphic level was assessed by calculating the PIC, which provides an estimate level of informativeness of SSR markers. SSR markers were considered to be informative if

$$
P I C=1-\left(\sum p i^{2}\right)^{2}
$$

with $\mathrm{PIC}=$ Polymorphic Information Content, $\mathrm{i}=1,2,3, \ldots \mathrm{n}, \mathrm{pi}^{2}$ is the $\mathrm{i}$-th allele frequency .

Principal component analysis (PCA), which is a multivariate technique, was peformed to analyze several variables, to identify the principal directions in which the data varies and to display the similarity of the pattern of observations and variables as points on a map. To determine genetic relationship among genotypes, clustering with the UPGMA (Unweighted 
Pair Group With Arithmetic mean) was carried out with NTSYS program (Rohlf, 1998) using XLStat 2013.

\section{RESULTS AND DISCUSSION}

Molecular screening by means of confirmation of SSR markers in their association with brown planthoppers (Bph) resistance genes in 20 genotypes is an essential effort for selecting promising parental for crossing and developing new genetic combination with some Bph genes in one genotype in order to create a horizontal resistance which is believed to be more durable. Molecular detection by using RM8072 as an example for detecting Bph3 gene wass presented in Figure 1. Results showed that PTB 33 (Bph3 with 146bp PCR product size referred to Gramene, 2008) had the same band with Inpari 13 (\#12), IR 64 (4), Ciherang (\#10), IR 42 (\#19), IR 74 (\#3), Aek Sibundong (\#5), Batang Gadis (\#6), Cibogo (\#7), Cisantana (\#8), Digul (\#9), Fatmawati (\#11), IR 66 (\#14), Mekongga (\#16) and Memberamo (\#17). Diah Suci (\#2) and Inpari 10 (\#13) had a slightly different size with PTB 33, meanwhile Taichung 65 (\#20), Kalimas (\#15) and Tukat Penatu (\#18) clearly had different band with PTB 33. Genotypes with the same banding pattern were suspected to have same Bph genes. According to the genome sequence of Nipponbare, Bph3 locus was finally localized approximately in a $190 \mathrm{~kb}$ interval flanked by marker RM19291 and RM8072, which contained twenty-two putative genes. This resistance gene has been identified and mapped on the short arm of chromosome 6 (Jairin et al., 2007b). It is very much believed that RM8072 is SSR marker that associated with Bph3 gene.

Table 2 showed compilation of the number of SSR markers detected in 20 genotypes. DNA banding pattern of each primer used in this study was presented. Form this table it was supposed that genotypes could be classified into three types of SSR markers they belong i.e.: (i) genotype with 0-2 SSR markers i.e.: IR 42 and Taicung genotypes; (ii) genotype with 3-5 SSR markers i.e.: IR 74, IR 64, Aek Sibundong, Batang Gadis, Cisantana, Inpari 10, IR 66, Kalimas, Menkongga, and Tukat Penatu genotypes; (iii) genotype with 6-8 SSR markers i.e.: PTB 33, Diah Suci, Cibogo, Digul, Ciherang, Inpari 13, and Memberamo. These data were consistent with the results of BPH resistance tests performed by Indonesian Rice Research Institute. Cultivar Inpari 13 proved to be resistant against BPH biotypes 1, 2, and 3, which was better than IR64 and Ciherang that only resistant to BPH biotypes 1 and 2 .

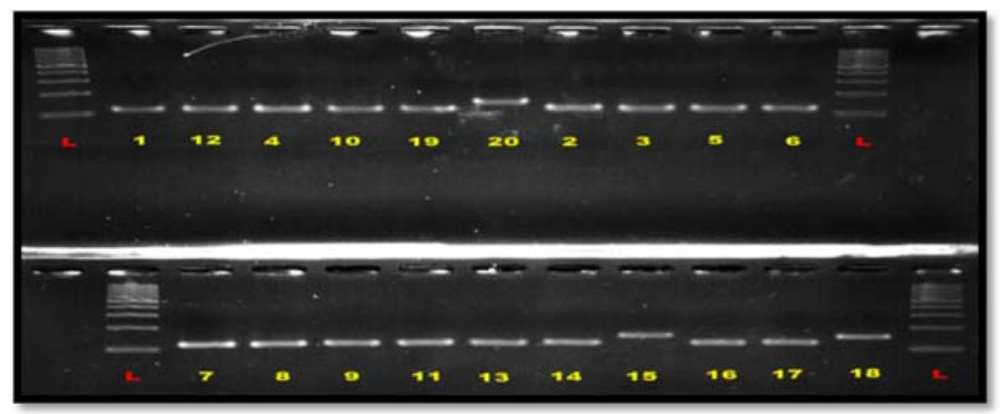

Figure 1. Visualisation of Agarose Gel Electrophoresis Using RM 8072 to Detect Bph3Gene (Ladder (L); PTB 33 (\#1); Diah Suci (\#2); IR 74 (\#3); IR 64 (\#4); Aek Sibundong (\#5); Batang Gadis (\#6); Cibogo (\#7); Cisantana (\#8); Digul (\#9); Ciherang (\#10); Fatmawati (\#11); Inpari 13 (\#12); Inpari 10 (\#13); IR 66 (\#14); Kalimas (\#15); Mekongga (\#16); Memberamo (\#17); Tukat Penatu (\#18); IR 42 (\#19); Taichung 65 (\#20) 
Results showed that Kalimas and Tukat Penatu had Qbph3, Bph3, and Qbph4 genes. According to the description of rice varieties published by Indonesian Rice Research Institute (2009), it was mentioned that Tukat Penatu was resistant to BPH biotype 3 and Kalimas was moderately resistant to BPH biotype 3 . Fatmawati was supposed to have Bph4 and $B p h 3$ which wass moderately resistant to BPH biotype 2 and biotype 3 . Cultivar IR 74 was found to have Bph3 and Qbph3genes, and Indonesia Rice Research Institute reported that this cultivar was resistant to BPH biotype 1 and biotype 2 .

Table 2. Number of SSR markers detected in 20 rice genotypes

\begin{tabular}{|c|c|c|c|c|c|c|c|c|c|}
\hline Genotypes & $\begin{array}{c}\text { RM } 7 \\
\text { (Qbph3) }\end{array}$ & $\begin{array}{l}\text { RM } 313 \\
\text { (Qbph3) }\end{array}$ & $\begin{array}{c}\text { RM } \\
8072 \\
\text { (Bph3) }\end{array}$ & $\begin{array}{c}\text { RM } \\
19291 \\
\text { (Bph3) }\end{array}$ & $\begin{array}{c}\text { RM } \\
5953 \\
(\text { Qbph4) }\end{array}$ & $\begin{array}{c}\text { RM } \\
8213 \\
(\text { Qbph4) }\end{array}$ & $\begin{array}{c}\text { RM } \\
586 \\
(\text { Bph3 } \\
\text { dan } \\
\text { Bph4) } \\
\end{array}$ & $\begin{array}{c}\text { RM } \\
589 \\
\text { (Bph3 } \\
\text { dan } \\
\text { Bph4) } \\
\end{array}$ & $\begin{array}{c}\text { Number } \\
\text { of } \\
\text { positive } \\
\text { detection }\end{array}$ \\
\hline PTB 33 (\#1) & + & + & + & + & + & + & + & + & 8 \\
\hline $\begin{array}{l}\text { Diah Suci } \\
\quad(\# 2)\end{array}$ & - & + & - & + & + & + & + & + & 6 \\
\hline IR 74 (\#3) & + & + & + & + & - & - & - & - & 4 \\
\hline IR 64 (\#4) & + & - & + & + & - & - & + & - & 4 \\
\hline $\begin{array}{c}\text { Aek } \\
\text { Sibundong } \\
(\# 5)\end{array}$ & + & - & + & + & - & - & + & - & 4 \\
\hline $\begin{array}{c}\text { Batang } \\
\text { Gadis (\#6) }\end{array}$ & + & - & + & + & - & - & + & - & 4 \\
\hline Cibogo (\#7) & + & + & + & + & - & + & + & - & 6 \\
\hline $\begin{array}{c}\text { Cisantana } \\
\quad(\# 8)\end{array}$ & + & - & + & + & - & + & + & - & 5 \\
\hline Digul (\#9) & + & - & + & + & + & - & + & + & 6 \\
\hline $\begin{array}{l}\text { Ciherang } \\
(\# 10)\end{array}$ & + & + & + & + & + & + & + & - & 7 \\
\hline $\begin{array}{l}\text { Fatmawati } \\
\quad(\# 11)\end{array}$ & - & - & + & + & - & - & + & - & 3 \\
\hline $\begin{array}{l}\text { Inpari } 13 \\
\quad(\# 12)\end{array}$ & + & + & + & + & + & + & + & - & 7 \\
\hline $\begin{array}{l}\text { Inpari } 10 \\
\quad(\# 13)\end{array}$ & + & - & - & + & - & + & + & - & 4 \\
\hline IR 66 (\#14) & + & + & + & - & - & - & - & + & 4 \\
\hline $\begin{array}{c}\text { Kalimas } \\
\text { (\#15) }\end{array}$ & + & + & - & + & + & + & - & - & 5 \\
\hline $\begin{array}{l}\text { Mekongga } \\
\quad(\# 16)\end{array}$ & + & + & + & + & - & - & + & - & 5 \\
\hline $\begin{array}{c}\text { Memberamo } \\
(\# 17)\end{array}$ & - & + & + & + & + & - & + & + & 6 \\
\hline $\begin{array}{c}\text { Tukat } \\
\text { Penatu } \\
(\# 18)\end{array}$ & + & + & - & + & + & - & - & - & 4 \\
\hline IR 42 (\#19) & - & - & + & + & - & - & - & - & 2 \\
\hline $\begin{array}{l}\text { Taichung } 65 \\
\qquad(\# 20)\end{array}$ & - & - & - & - & - & - & - & - & 0 \\
\hline
\end{tabular}

Note: $(+)=$ Supposed to have resistance gene, $(-)=$ Supposed do not have resistance gene

Based on Table 2, Memberamo and Diah Suci had Qbph3, Qbph4, Bph3, and Bph4 genes. These varieties were resistant to brown planthopper biotypes 1,2 , and were moderately resistant to biotype 3. Meanwhile, although Inpari 10 had Qbph3, Qbph4, Bph3, and $B p h 4$, these cultivars were identified as slightly resistant to BPH biotype 1 and 2 (Suprihatno 
et al., 2010). This might be due to resistance to BPH is not governed by a single gene but controlled by many genes (Nugaliyadde et al, 2000; Jairin et al, 2005; Chen et al, 2006; Murata, 1998).

In general, genotypes PTB 33, Diah Suci, Cibogo, Cisantana, Digul, Ciherang, Inpari 13, Kalimas, Mekongga, and Memberamo were well serve as parent because positively detected as having resistance genes using many markers (Table 2). The more Bph genes they have the more resistant they were expected.

\section{PIC (Polymorphic Information Content)}

The polymorphic information content of 8 SSR markers used in this study was presented in Table 3. Based on Table 3, RM313, RM8072, RM5953, RM8213, RM586, and RM589 were considered as informative markers, while RM7 and RM19291 were classified as uninformative markers. This criterion refers to Zhang et al. (2011) who stated that if the PIC values $e^{\prime \prime} 0.5$, then the markers are classified to be informative. The greater the PIC value corresponds to the better primer to be molecular markers (Anderson et al., 1993).

It was found that sometimes PCR product of informative markers was not polymorphic, which may hinder the analysis. This might be related to the purity of genomic DNA used for amplification. In such case, DNA extraction, PCR reaction and electrophoresis were repeated again in assuring a trusted data. Optimization was also performed for various conditions such as concentration of DNA polymerase, annealing temperature, concentration of DNA samples and the length of the PCR process. The success of DNA amplification was also influenced by the purity and integrity of the DNA samples (Bardakci, 2001) but in some genomes, the purity of the DNA samples did not affect amplification (Caetano-Anollés, 2004). DNA concentration which is too high may increase the contaminants that interferes amplification reaction (Chen, 2000).

Table 3. Polymorphic Information Content (PIC) of SSR markers

\begin{tabular}{lcccc}
\hline \multicolumn{1}{c}{ Markers } & $\begin{array}{c}\text { PCR product } \\
\text { Size }\end{array}$ & Number of band & Number of Allele & PIC \\
\hline RM7 (Qbph3) & $180 \mathrm{bp}$ & 19 & 3 & 0,42 \\
RM313 (Qbph3) & $111 \mathrm{bp}$ & 20 & 5 & 0,73 \\
RM19291(Bph3) & $146 \mathrm{bp}$ & 20 & 4 & 0,35 \\
RM8072 (Bph3) & $146 \mathrm{bp}$ & 20 & 7 & 0,66 \\
RM5953 (Qbph4) & $129 \mathrm{bp}$ & 20 & 3 & 0,54 \\
RM8213 (Qbph4) & $177 \mathrm{bp}$ & 29 & 3 & 0,63 \\
RM586 (Bph3 \& Bph4) & $271 \mathrm{bp}$ & 20 & 5 & 0,76 \\
RM589 (Bph3 \& Bph4) & $186 \mathrm{bp}$ & 20 & 5 & 0,77 \\
\hline
\end{tabular}

\section{Principal Component Analysis}

Based on result of principal component analysis (PCA) presented in Figure 2, there were three main groups identified. Group one consisted of PTB-33, Tukat Penatu, Memberamo, Diah Suci, Kalimas, IR-74 and IR-66 genotypes. Taichung-65 was separated as group two, and the other genotypes clustered together in group three. Genotypes clustered in group one was thought to have Bph resistance gene close to PTB-33, whereas Taichung-65 (susceptible genotype) did not have Bph resistance gene as has been reported in previous studies, and located on the opposite site with quadrant of PTB-33 on the PCA plot. 


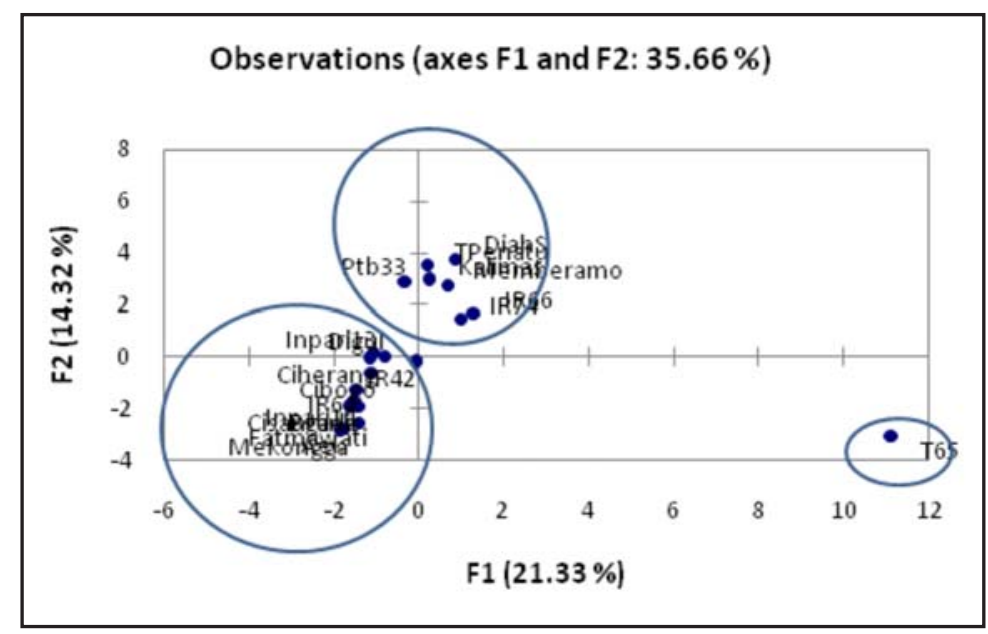

Figure 2. PCA of 20 Rice Genotypes

\section{Genetic Relationship}

Results of cluster analysis on 20 rice genotypes using eight SSR markers was shown in Figure 3. This grouping of genotypes was resulted based on molecular data using UPGMA Jaccard's coefficient using XLSTAT 2013 program to determine a genetic relationship based on the presence of Bph genes. Two main clusters were recognized, with the first cluster consistsed of 2 sub clusters. The first sub cluster was formed by PTB 33, Memberamo, Tukat Penatu, Digul, Diah Suci, Kalimas, while IR 64, Cisantana, Inpari 10, Aek Sibundong, Mekongga, Batang Gadis, Fatmawati, Cibogo, Ciherang, Inpari 13 formed the second sub cluster. The first and second sub cluster joined by coefficient value of 3.25. The second cluster consisted of IR 74, IR 66 and IR 42 and joined with the first cluster by coefficient value of 3.49 .

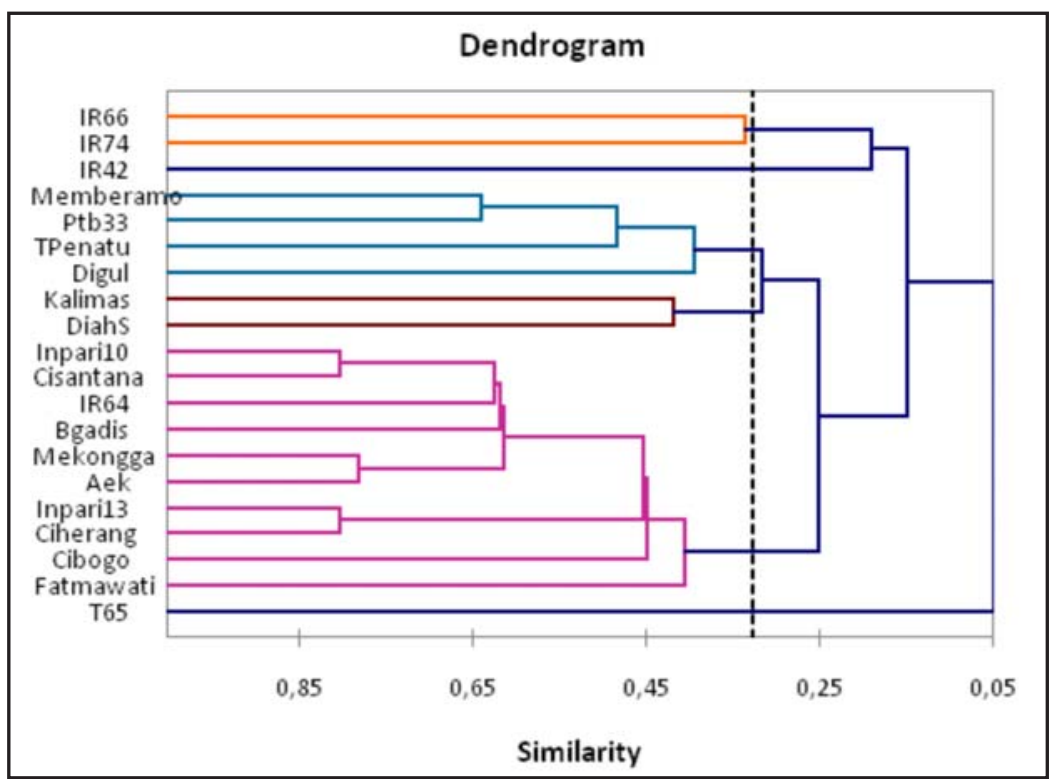

Figure 3. Clustering Analysis of 20 Rice Genotypes based on 8 SSR Markers

Figure 3 revealed that the smaller coefficient value between genotypes indicated that they were closely related in terms of resistance gene to BPH. PTB 33 was known to be resistant to $\mathrm{BPH}$ along with Memberamo, Tukat Penatu, Digul, Diah Suci, and Kalimas. 
Based on the results of SSR, the PTB 33, Memberamo, Digul, and Diah Suci was supposed to have Qbph3 gene, Bph3, Qbph4, and Bph4, as well as Tukat Penatu and Kalimas which have Qbph3, Bph3, and Qbph4. These genotypes were thought to have similar genes that resistant to $\mathrm{BPH}$.

\section{CONCLUSION}

1. The informative SSR markers were RM586, RM589, RM313, RM8072, RM5953 and RM 8213 while the uninformative markers were RM7 and RM19291.

2. The SSR markers used in this study were capable of detecting the presence of Bph genes.

3. Genetic relationship based on the presence of Bph genes showed that PTB 33 was closely related to Memberamo, Tukat Penatu, Digul, Diah Suci, and Kalimas.

\section{REFERENCES}

Anderson, J.A., G.A. Churchill, J.E. Autrique, S.D. Tanksley, and M.E. Sorrells. 1993. Optimizing parental selection for genetic linkage maps. Genome 36: 181-186.

Baehaki. 2007. Population development of brown planthoppers biotype 4 (in Bahasa Indonesia). Jakarta: Gramedia.

Bardakci, F. 2001. Random amplified polymorphic DNA (RAPD) markers. Turk. J. Biol. 25:185-196.

Botstein, D., R.L. White, M. Skolnick, and R.W. Davis. 1980. Construction of a genetic linkage map in man using restriction fragment length polymorphisms. Am J Hum Genet32:314331.

Caetano-Anollés, G. 2004. DNA amplification fingerprinting. a forum for DNA marker methodologies: University of Illinois at Urbana- Champaign.

Chen, H.A. 2000. PCR. Chen's own protocols: Chen's protocol list: PCR. http://users. breathe.com/hachen/protocols/PCR.html

Chen, J.W., L. Wang, X.F. Pang, and H.Q. Pan. 2006. Genetic analysis and fine mapping of a rice brown planthopper (Nilaparvata lugens Stål) resistance gene bph19(t). Mol. Genet. Genomics 275: 321-329.

Doyle, J.J., and E.E. Dickson. 1987. Preservation of plant samples for DNA restriction endonuclease analysis. Taxon 36:715-722.

Foulet, F., N. Nicolas, O. Eloy, F. Botterel, J.C. Gantier, J.M. Costa, and S. Bretagne. 2005. Microsatellite marker analysis as a typing system for candidate glabrata. Journal of Clinical Microbiology 43(9) : 4574-4579.

Gramene. 2008. Primer. http://www.gramene.org/Multi/psychic?site=gramene_ensemb/\& species=Oryza_sativa\&q=primer. Accessed 2 January 2012.

Jairin, J., K. Phengrat, S. Teangdeerith, A. Vanavichit, and T. Toojinda. 2007a. Mapping of a broadspectrum brown planthopper resistance gene, Bph3, on rice chromosome 6. Mol. Breed., 2007a, 19, 35-44.

Jairin, J., S. Teangdeerith, P. Leelagud, K. Phengrat, A. Vanavichit, and T. Toojinda. $2007 \mathrm{~b}$. Physical mapping of Bph3, a brown planthopper resistance locus in rice. Mj. Int. J. Sci. Tech. 2007b, 01(2), 166-177 
Kisimoto, R. 1981. Development, behavior, population dynamics and control of the brown planthopper, Nilapavarta lugens Stal. Rev. Plt. Protect. Res. 14:26-58.

Liu, B.H. 1998. Statistical genomics, linkage mapping, and QTL analysis. CRC Press. New York. p.45-83

Mochida, O., T. Suryana, Hendarsih, and A. Wahyu. 1978. In The Brown Planthopper. Proc. Symp. Brown Planthopper. The 3rd Inter-Congress of the Pacif. Sci. Ass., Bali, Indonesia, 22-23 July 1977. p. 1-39.

Murata, K. 1998. Molecular linkage analysis of brown planthopper resistance genes in rice. The Graduate School of Science and Technology, Kobe University.

Nugaliyadde, L., D.M.N. Dissanayake, and J. Mitrasena. 2000. Advances of pest and disease management of rice in Sri Lanka. Department of Agriculture, Peradeniya. Sri Lanka.

Rohlf, F.J. 1998. Numerical taxonomy and analysis system (NTSYSpc) version 2.0. New York: Department of Ecology and Evolution Sate University of New York.

Sharma, P.N., A. Tori, S. Takumi, N. Mori, and C. Nakamura. 2003. Marker-assisted pyramiding of brown planthopper (Nilapavarta lugens Stal) resistance gene Bph1 and Bph2 on rice chromosome 12. Laboratory of Plant Genetics, Department of Biological and Environmental Science, Faculty of Agriculture, and Division of Life Science, Graduate School of Science and Technology, Kobe University, Kobe, Japan.

Sun, L., C. Su, C. Wang, H. Zhai, and J. Wan. 2005. Mapping of a major resistance gene to the brown planthopper in the rice cultivar Rathu Heenati. Breed. Sci. 55: 391-396.

Suprihatno, B., A.A. Daradjat, Satoto, S.E. Baehaki, Suprihanto, A. Setyono, S.D. Indrasari, I.P. Wardana, and H. Sembiring. 2010. Description of Rice Varieties (In Bahasa Indonesia: Deskripsi Varietas Padi). BB Penelitian Tanaman Padi. Badan Penelitian dan Pengembangan Pertanian. Departemen Pertanian.

Zhang, Y., X.F. Wang, Z.K. Li, G.Y. Zhang, and Z.Y. Ma. 2011. Assessing genetic diversity of cotton cultivars using genomic and newly developed expressed sequence tag-derived microsatellite markers. Hebei Agricultural University, Baoding, China. Genetics and Molecular research 10 (3): 1462-1470. 